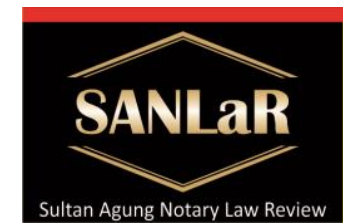

Volume 3 No. 1, March 2021
Sultan Aqung

Notary Law Review

ISSN 2686-4428

published by

Master of Notarial Law

Universitas Islam Sultan Agung Semarang

Legal Power and Government...(Rezky Della Putri Waluyo)

\title{
Legal Power and Government Authority in the Implementation of Land Acquisition for Public Interest
}

\author{
Rezky Della Putri Waluyo*), Amin Purnawan ${ }^{* *}$ and Maryanto**)
}

*) Student of Master of Notary Law, Faculty of Law, Universitas Islam Sultan Agung (UNISSULA) Semarang, E-mail: rezkydella99@gmail.com

$\left.{ }^{* *}\right)$ Lecturer of Master of Notary Law, Faculty of Law, Universitas Islam Sultan Agung (UNISSULA) Semarang

$\left.{ }^{* * *}\right)$ Lecturer of Master of Notary Law, Faculty of Law, Universitas Islam Sultan Agung (UNISSULA) Semarang

\begin{abstract}
This study aims to analyze the legal strength and authority of local governments in the implementation of land acquisition for the public interest based on statutory regulations, to explain the constraints and solutions for implementing land acquisition for the public interest in Banyumas Regency. The approach method in this research is juridical empirical. The research specification used is descriptive analytical. Sources of data used in this study consist of primary data and secondary data which can be distinguished into primary legal materials, secondary legal materials, and tertiary legal materials. Collecting data in this study using literature study and interviews. The data analysis technique used is that the analyzed data will be presented in the form of qualitative data analysis. Based on this research, it can be concluded that the regulation of regional government authority in terms of land acquisition for the public interest is based on the provisions of Article 47 Paragraph (1) Presidential Regulation Number 148 of 2015 concerning Implementation of Land Acquisition for Development for Public Interest, the Governor with the authority he has can conduct land for public use. The governor in this case can carry out his own authority in the preparation of land acquisition or delegate it to the Regent and in the implementation of the authority of the regional government in land acquisition for public interest in Banyumas Regency, it is in accordance with Act No 2 of 2012 concerning Land Acquisition for Development for Public Interest, namely from the planning stage, the preparation stage, and implementation.
\end{abstract}

Keywords: Local Government Authority; Land Procurement; Public interest.

\section{Introduction}

Land acquisition is very vulnerable in its handling because it involves the interests of many people. When viewed from the government's need for land for development purposes, it can be understood that the available state land is very limited. Therefore, the method that can be taken is by acquiring land that belongs to the community, whether it has been controlled by rights based on customary law or other rights 
according to the prevailing laws and regulations. Considering that land is one of the most important elements in carrying out development, the government's action is to realize legal certainty of land rights based on the 1945 Constitution of the Republic of Indonesia, hereinafter referred to as the 1945 Constitution Article 33 Paragraph (3) which reads: "Earth and water and the wealth contained therein shall be controlled by the state and used for the greatest prosperity of the people". In other words, Article 33 Paragraph (3) above explains that it is prohibited to control natural resources in the hands of individuals or individuals. In other words, monopoly cannot be justified, but current facts apply in business, business and investment practices in the field of natural resource management to some extent contrary to the principles of Article 33. Land acquisition is any activity to acquire land by means of compensation to who hand over land, buildings, and objects related to land. The land acquisition process has also never been separated from the problem of compensation. Therefore, it is necessary to conduct research in advance of the data and information to obtain an estimate of the provision of land compensation. So that if an agreement has been reached regarding the form and amount of compensation to be paid, a compensation payment that has been agreed upon will then be made to transfer the rights to the land concerned.

The implementation of land acquisition in its implementation is a complex problem because there are several stages and processes that are passed and the interests of conflicting parties. The issue of acquiring land belonging to the community for the public interest is a quite complex issue. The need for land, either by the government or by the community, which continues to increase without being followed by an increase in large areas of land, is a very important problem. This problem arises because of a clash of interests. On the other hand, the government needs land for physical development, on the other hand, the community needs land for livelihoods or settlements and land acquisition for public purposes is an activity that provides land by providing appropriate and fair compensation to those who are entitled ${ }^{1}$.

Nowadays, it is very difficult to carry out development for the public interest on state land. However, in reality, it shows that development requires land, but on the other hand, existing State land to meet these needs is increasingly limited, because the existing land is partly owned by the community with a right. In order for development to be maintained, especially the construction of various facilities for public interests, which require land, then legal efforts from the government to acquire the land in order to fulfill development are carried out through the approach of rights release or revocation of rights. Therefore, the way out is taken by taking land rights. Activities to acquire land by providing compensation by the Government in the context of implementing development for the public interest.

However, in reality, in the practice of land acquisition for the public interest, landowners lack legal protection and there is no common understanding and attitude towards its implementation, including court bodies in carrying out the policies contained in these regulations, so that it creates an impression as if the law does not provide enough. legal protection for people whose land is used for public interest. Therefore, the government's efforts in carrying out development, every policy that will

1 Soimin, Soedharyo. (1993). Status Hak dan Pengadaan Tanah, Jakarta: Sinar Grafika. p. 75. 
be taken must be done carefully and wisely. Land acquisition is the first step taken when the government needs land for public interest ${ }^{2}$.

The mechanism for taking people's lands often creates problems. Therefore, the implementation of land acquisition is carried out by taking into account the role and function of land in human life and the principle of respecting legal rights to land. Therefore, land acquisition for the public interest is endeavored in a balanced manner and is pursued by way of direct deliberation with the holders of the said land rights. However, if the number of holders of land rights does not allow the deliberations to be held effectively, then the deliberations will be carried out by the Land Acquisition Committee and Government Agencies that require land with representatives appointed by the holders of land rights. If land acquisition through deliberation does not find a solution between government agencies and land rights holders, meanwhile, the land will be used for public purposes, therefore, the revocation of land rights which have been regulated in Act No 20 of 1961 concerning Revocation of Land Rights and the Objects on it will be taken. As the organizer of land acquisition, the government must also carry out the mandate contained in the Law which prioritizes the interests of the people, so as not to harm the interests of the people. To ensure legal certainty and issues of land acquisition for development in the public interest, the government compiles laws and regulations that regulate this matter. Acquisition of land by the government from the community for development in the public interest can be carried out through a series of stages that must be passed, namely: Through revocation of land rights. The legal basis for taking land through this mechanism is contained in Article 18 of the UUPA, which reads: "For the public interest, including the interests of the nation and the State as well as the common interests of the people, land rights can be revoked, by providing appropriate compensation and in a regulated manner Constitution." Through land exchange and sale and purchase of land rights according to customary law ${ }^{3}$.

The authority of the government and local governments related to the land sector in this autonomy era, is that the authority in the land sector has not been handed over to the regional government, it is better if the authority in the land sector is given to the local government based on the criteria of granting authority efficiently it will be more beneficial and useful for the region in the welfare of the people. regions through regulations related to the land sector managed by the local people. This is because the regional government is much more aware of the real land needs of the area and the authority in the land sector is a source of income for the region which is used for the welfare of the people of the region.

Procurement of land for public interest in Banyumas Regency raises several problems including land acquisition for the construction of Underpass General Soedirman Purwokerto, Banyumas Regency regarding compensation which sometimes does not match the land price in general or the return of land rights from the community to local governments which caused by land acquisition, road widening or construction of new roads in Banyumas Regency. Regarding the impacts that are the impact of land

2 Sutendi, Adrian. (2008). Implementasi Prinsip Kepentingan Umum Dalam Pengadaan Tanah Untuk Pembangunan. Jakarta: SinarGrafika. p. 49.

3 Salindheo, John. (1998). Masalah Tanah Dalam Pembangunan Ed.2. Jakarta: Sinar Grafika. p. 84. 
acquisition, road widening or construction of new roads, the impact is not only the upper middle class of society but also many middle and lower class communities.

Based on the background description of the problem above, a problem formula can be formulated as follows:

1. What is the legal power and authority of local governments in the implementation of land acquisition for the public interest based on statutory regulations?

2. What are the obstacles and solutions for implementing land acquisition for the public interest in Banyumas Regency?

\section{Research Methods}

This approach method uses juridical empirical method which is intended to explain the problems under study with the results of the research obtained in relation to the legal and reality aspects that occur in the implementation of Land Acquisition for Public Interest in Banyumas Regency. The research specification used in this research is descriptive analytical. The research approach used is juridical empirical, so the main data used in this study are primary data and secondary data, data collection methods used are in the form of literature study and interviews. Methods of data analysis in this study using qualitative data analysis methods.

\section{Results and Discussion}

3.1 Legal Power and Authority of Local Governments in Implementing Land Acquisition for Public Interest in Banyumas Regency Land acquisition in Banyumas Regency is Land Acquisition for General Soedirman Purwokerto's Underpass. In accordance with the provisions of Article 45 of Presidential Regulation Number 71 of 2012 concerning Implementation of Land Acquisition for Development for Public Interest, a construction location for road construction is determined in Banyumas Regency, namely St. Sokajati, Bantarsoka Village, West Purwokerto District. The purpose and objective of the construction of the General Soedirman Purwokerto Underpass is to unravel the congestion at a level crossing of St. Jenderal Soedirman west of Purwokerto Station, especially when a train is passing. Construction construction period for 1 fiscal year.

According to the government division of the regional secretary of Banyumas Regency, the implementation of regional government authority arrangements in land acquisition for the public interest in Banyumas Regency through several stages, namely land acquisition for the construction of General Soedirman's Underpass carried out based on Article 2 of Presidential Regulation Number 71 of 2012 concerning Implementation of Land Acquisition for Development for Public Interest, starting from the planning stage, preparation, implementation, and submission of results.

1) Planning

The planning stage in land acquisition for the construction of General Soedirman's Underpass starts from February 2018. The development will be divided into 2 (two) parts. Eastern part and western part.

2) Preparation 
After the planning stage is completed, the land acquisition for the construction of General Soedral's Underpass enters the preparation stage, where the Governor has received the land acquisition planning document. And the Banyumas Regency government has started to organize socialization in the village. Among them, as an example of the first socialization carried out in West Purwokerto Subdistrict, namely in the Pendopo of Bantarsoka Village by holding face-to-face meetings with elements of society and local government. The socialization was attended by:

a) Banyumas Regency National Land Agency

b) DPPKAD Banyumas Regency

c) Head of the Environment Agency of Banyumas Regency

d) Secretary of the SDABM Office of Banyumas Regency

e) Head of Bapedda Praswil, Banyumas Regency

f) Dinhubkominfo Banyumas Regency.

During the socialization, a meeting was held with the West Purwokerto Muspika, the Head of West Purwokerto Urban Village, the heads of RT and RW, community organizations, and community leaders, and of course land owners affected by land acquisition. It was stated that the plan for the construction of the Underpass General Soedirman Purwokerto which will be divided into two (2) parts, namely the east side and the west side and has carried out the reconstruction of a 68.03 kilometer long national road in Banyumas Regency. The socialization was carried out in West Purwokerto Subdistrict, namely at the LPMK Hall, Bantarsoka Village. The socialization was attended by:

a) National Land Agency of Banyumas Regency

b) Cleanliness and Spatial Planning Office of Banyumas Regency

c) DPPKAD Banyumas Regency

d) West Purwokerto Muspika

e) Head of RT and RW of Bantarsoka Village

f) Community leaders and institutions of Bantarsoka Village

g) Land owners who are affected by land acquisition

3) Implementation

After the planning and preparation stages are carried out, land acquisition for the construction of the Jendar Soedirman Purwokerto Underpass enters the implementation stage, namely starting to take measurements which include:

a) Juridical research on land ownership

b) Count and identify buildings that are above and below ground level

c) Count and identify growing crops

4) Submission of Results

According to the author, the state or government agencies have the authority to conduct land acquisition for the implementation of development for the public interest based on the provisions of Article 6 of Act No 2 of 2012 concerning Land Acquisition for Development for Public Interest which determines that "Land procurement for public interest is carried out by Government". Regarding land acquisition, based on the provisions of Article 8 Paragraph (1) of Presidential Regulation Number 148 of 2015, it is explained: "The governor carries out the stages of land acquisition preparation activities after receiving the land acquisition planning document". Furthermore, Article 
47 Paragraph (1) of Presidential Regulation Number 148 of 2015 states: "The governor can delegate the authority to carry out the preparation of land acquisition for development in the public interest to the Regent/Mayor."

Based on the aforementioned provisions, the Governor, with the authority he has, can carry out land acquisition for the implementation of development for the public interest.

So the implementation of the land acquisition process for the implementation of development for the public interest as regulated in Presidential Regulation Number 71 of 2012 in conjunction with Article 148 of 2015 concerning Implementation of Land Acquisition for Development for Public Interest, is the authority of the Governor as the Provincial Government. In this case, the governor can carry out his own authority in the preparation of land acquisition or delegate it to the Regent/Mayor.

Therefore, in the case of land acquisition for the public interest in Banyumas Regency in the construction of General Sudirman's Underpass, the Governor can carry out his own authority in preparing the land acquisition and delegate it to the Banyumas Regent.

Concurrent governmental affairs transferred to the regions are the basis for the implementation of regional autonomy. Where the government affairs are located in the Regency/City area, the users are in the Regency/City area, the benefits or negative impacts are only in the Regency/City area, and the use of the resources is more efficient if it is carried out by the Regency/City area. And according to the author, the implementation of land acquisition for the public interest in Banyumas Regency in the construction of General Soedirman's Underpass is in accordance with the applicable laws and regulations, namely carried out through stages based on Article 2 of Presidential Regulation Number 71 of 2012 in conjunction with Presidential Regulation Number 148 of 2015 regarding the Implementation of Land Acquisition for Development for Public Interest, namely through the stages of preparation, planning, In the first stage, planning, is in accordance with Article 3 of Presidential Regulation Number 71 of 2012 in conjunction with Presidential Regulation Number 148 of 2015 concerning Implementation of Land Acquisition for Development for Public Interest, namely planning based on the Regional Spatial Plan and development priorities listed in the Development Plan. Medium Term, Strategic Plan, Government Work Plan of the relevant agency. And after that it is compiled in the form of a land acquisition planning document in accordance with Article 5 of Presidential Regulation Number 71 of 2012 in conjunction with Presidential Regulation Number 148 of 2015 concerning Implementation of Land Acquisition for Development for Public Interest.

After the land acquisition planning stage, the construction of the Underpass General Soedirman entered the preparation stage, which in this case is in accordance with Article 46 of Presidential Regulation Number 148 of 2015, namely the first thing the government does is that the government determines the location of land acquisition, and in this case the Banyumas Regent determines the location. land acquisition and announce it to the relevant agencies. However, the submission of the location for land acquisition is not in accordance with Article 46 Paragraph (2) of Act No 148 of 2015 where the announcement must have been announced 2 (two) days from the 
determination of the location, but in fact the announcement will only be made 1 (one) week later.

After the planning and preparation stages are carried out, land acquisition for the construction of General Soedirman's Underpass enters the implementation stage, namely starting to take measurements which include:

a. Juridical research on land ownership;

b. Count and identify buildings that are above and below ground level;

c. Count and identify the crop growing

When the land acquisition team was formed, this was determined by the Regent and the Head of the Land Office, as well as the sub-district where the road was widening. The Head of the BPN Regional Office may assign the Head of the Land Office as the Head of Land Acquisition, by taking into account efficiency, effectiveness, geographical conditions, and human resources, within 2 (two) working days from the receipt of the Land Acquisition Implementation application.

This is in accordance with Article 49 Paragraph 3 of Presidential Regulation Number 148 of 2015, where the membership composition of the land acquisition executor at least contains the following elements:

a. Officials in charge of land acquisition affairs in the BPN Regional Office;

b. Head of the local Land Office at the land acquisition location;

c. Officials of provincial work units in charge of land affairs;

d. The local subdistrict head at the land acquisition location; and Lurah/village head or other names at the location of land acquisition.

In the implementation of the land acquisition process for the implementation of development for the public interest as regulated in Article 71 of 2012 which was later amended into Presidential Regulation Article 148 of 2015 concerning Implementation of Land Acquisition for Development for Public Interest, it is the authority of the Governor as the Provincial Government which can be delegated to the Regent/Mayor based on the principle of regional autonomy.

The road widening was carried out after the Governor received the land acquisition plan document, this was in accordance with Article 8 of Presidential Regulation Number 148 of 2015.

In carrying out road widening activities, the chief executor of land acquisition may form a task force within 2 (two) working days of the establishment of the land acquisition executor, which is in charge of inventory and identification of physical data on control, ownership, use and utilization of land; and data of entitled parties and land acquisition objects.

So, according to the author, the implementation of local government authority in land acquisition for the public interest in Banyumas Regency is carried out based on Article 6 of Act No 12 of 2012, which states that land acquisition for public purposes is carried out by the Government. The authority of the Regional Government in land acquisition for public interests in Banyumas Regency is the authority of the Regional Government in providing land for development for public interests. According to the provisions of Article 8 of Presidential Regulation Number 148 of 2015, it is explained that "the Governor will carry out the stages of land acquisition preparation activities after receiving the land acquisition planning document". Furthermore, Article 47 paragraph 
(1) of Presidential Regulation Number 148 of 2015 states "Governors can delegate the authority to carry out land acquisition preparations for development in the public interest of the Regent/Mayor". Therefore, in this case the Governor can exercise his own authority in the preparation of land acquisition and delegate it to the Banyumas Regent.

\subsection{Constraints and Solutions for Land Acquisition Implementation for Public Interest in Banyumas Regency}

Land acquisition is the activity of providing land by providing appropriate and fair compensation to entitled parties. This is based on the fact that land is social in nature so that the State in this case the government has the authority to manage the earth, water and space for the greatest possible prosperity of the people.

However, the reality is that in land acquisition there are always obstacles that occur. This is because land is a very important property right for humans to carry out various activities on it. So that land acquisition carried out by the government for the purpose of public interest is not always responded positively by the community.

Some of the obstacles that are often faced are due to the fact that there are still some residents who do not agree on the value of compensation payments for land acquisition. If the compensation payments are not immediately implemented optimally in accordance with the policies that have been made, the implementation of road construction will be detrimental to the community because project-affected residents will lose their land rights by revoking their land rights by the government.

In procuring land for the construction of General Soedirman's Underpass, several land owners whose land is affected by road projects for the public interest try to defend their land at a price according to the general selling value or market price in the area, whereas because this is for the public interest the price proposed by the government it is indeed lower than the general selling price or market price in the region, making the execution process difficult.

So that there were obstacles in the process of land acquisition stages to reach the handover process. In fact, the budget for the financing of the development plan, which is estimated to be up to 30 (thirty) billion, must be released immediately in order to meet the target of a smooth realization of the Regional Budget. For this reason, in land acquisition in the construction of General Soedirman's Underpass, consultation procedures are carried out to overcome these obstacles and approaches to be accepted and understood by the community regarding the social functions contained in each land right as stated in Article 6 of Act No 5 of 1960. regarding Agrarian Principles, which explains that all land rights that belong to a person cannot be used solely for their personal interests,

In Article 1 point 8 of Presidential Regulation Number 71 of 2012 it is explained that "public consultation is a process of dialogical communication or deliberation between interested parties in order to reach an understanding and agreement in land acquisition planning for development in the public interest." Deliberation itself is regulated in Article 68 through Article 73 of Presidential Regulation Number 71 of 2012. 
According to Act No 2 of 2012 concerning Land Acquisition for Development for Public Interest, compensation is a reasonable and fair compensation to the entitled parties in the land acquisition process. The form of compensation according to Article 74 of Presidential Regulation Number 71 of 2012 can be in the form of money, replacement land, resettlement, share ownership, or other forms that are mutually agreed upon at the deliberation.

Article 23 of Act No 2 of 2012 concerning Land Acquisition for Development for Public Interest regulates the refusal of parties entitled to determine the location of development where the entitled parties can file a lawsuit at the State Administrative Court. Whereas in the event that there is no agreement regarding the form and/or amount of compensation, land rights holders who do not accept the decision of the land acquisition committee regarding the form and amount of compensation are based on the provisions of Article 73 of Presidential Regulation Number 71 of 2012 concerning Implementation of Land Acquisition for Development for the The public can file a lawsuit at the Local District Court. The price set by the executor of land acquisition is based on the real value, namely the Tax Object Selling Value (NJOP).

In this determination, there were several conflicts of interest between public interests and individual/private interests. The residents' refusal due to the widening of this road is quite reasonable, because they have been doing business and living for years, and some do not agree with the estimated amount of compensation for the land affected by the land acquisition. Therefore, the government of Banyumas Regency used the method of reconsulting with the community who did not agree on the amount of compensation and held another deliberation. Through the deliberation, it was given a re-understanding of the social functions contained in each land right as stated in Article 6 of Act No 5 of 1960 concerning Agrarian Principles,

Finally, some residents who previously disagreed about the amount of compensation after consultation and approach by government agencies, some of these citizens began to realize that as good citizens, they must prioritize public interests over personal interests, although there are still some who have already held consultations and deliberations. back to maintaining the terms of the price proposed by the holders of land rights. And consultations and deliberations will be carried out again with those who still do not agree.

According to the author, the obstacles in exercising local government authority in land acquisition for the public interest in Banyumas Regency are the amount of compensation, namely the disagreement in the price proposed by the government and the holders of land rights. Land appraisers tend to use the Tax Object Selling Value (NJOP) as a reference in determining the price for compensation for land affected by land acquisition, while land rights holders want the compensation price for Land Acquisition Objects to be according to market prices, considering the impact of this land acquisition in addition to them. losing their land or residence that has historical and cultural value, they also suffer losses if the price of their land is sold at a price they think is not in accordance with what they are releasing. Meanwhile, the limited government budget in providing the budget cannot provide a nominal value in accordance with the wishes of the people. So that in land acquisition for the construction of General Soedirman's Underpass, the process will be slightly hampered 
because the government determines the compensation price according to the Tax Object Selling Value where if the land price is determined based on the Tax Object Selling Value, it must be lower than the general price/market price.

If there is no agreement regarding the amount of compensation, in fact the objecting party has the right to file an objection to the local District Court within 14 (fourteen) days after deliberation on the determination of compensation, in accordance with the provisions of Article 38 Paragraph (1) of Act No 2 of 2012 concerning Land Acquisition for Development for Public Interest. However, during the period referred to in Article 38 Paragraph (1) if no one files a lawsuit, it is because of the law that the entitled Party is deemed to have received the form and amount of compensation. According to the author, looking at the provisions above, holders of land rights affected by land acquisition, who do not agree with the amount of compensation based on the results of negotiations, actually get legal protection from legislation. that is, they can file an objection to the local District Court. And land rights holders cannot be forcibly evicted because based on Article 5 of Act No 2 of 2012 concerning Land Acquisition for Development for Public Interest, land owners are required to release land for the public interest after giving compensation or based on a court decision that has obtained legal force. permanent. If as long as there is no agreement regarding compensation and no compensation has been provided, it means that the land owner or land rights holder affected by the land acquisition is not obliged to release the land. The land owner is obliged to release the land for public interest after giving compensation or based on a court decision that has obtained permanent legal force. If as long as there is no agreement regarding compensation and no compensation has been provided, it means that the land owner or land rights holder affected by the land acquisition is not obliged to release the land. The land owner is obliged to release the land for public interest after giving compensation or based on a court decision that has obtained permanent legal force. If as long as there is no agreement regarding compensation and no compensation has been provided, it means that the land owner or land rights holder affected by the land acquisition is not obliged to release the land. And according to the author, to overcome this problem, it is true that the Banyumas Regency government uses a way of consultation and re-deliberation with people who do not agree on the amount of compensation and hold another deliberation. Because the deliberation is then given a re-understanding of the social functions contained in each land right as stated in Article 6 of Act No 5 of 1960 concerning Agrarian Principles, which explains that all rights to any land belong to a person. should not be used solely for their personal interests, but also the use of the land must provide benefits for the interests of the community and the state, that is a good approach, so that the community will better understand, understand,

It would be nice if the need for rules or provisions regarding procedures for calculating compensation for compensation is also socialized to all parties, in order to obtain transparency regarding the value of compensation provided. In addition, an approach is made to the communities affected by land acquisition by increasing the support and respect for land rights owners by promoting more comprehensive socialization, negotiation and compensation. 
In addition, it should not be forgotten that the interpretation of the principle of social function of land rights must be used in accordance with the nature and purpose of the rights, so that it is beneficial for the holder of the land rights and for the community, and that individual interests are recognized and respected in the context of implementing the public interest in a manner. whole. This means that there must be a balance between individual interests and public interests so that with a balance between these two interests, it is hoped that justice and the welfare of all people can be achieved.

The following are the obstacles in exercising local government authority in land acquisition for the public interest in Banyumas Regency and solutions to overcome these obstacles:

No. Constraints

1 Many people do not understand and realize about goals for the public interest

2

Multiple holders land rights do not agree regarding the amount of compensation proposed by the government to the holders of land rights

$3 \quad$ Limited government budget for land acquisition

\section{Solution}

Socialization was carried out with the community

Public consultations and deliberations with land rights holders who do not agree on compensation are conducted

\section{Raise the Facebook budget}

Can compensate the owners of land rights affected by land acquisition fairly and fairly

\section{Closing}

\subsection{Conclusion}

The regulation of the authority of the regional government in terms of land acquisition for public interests based on legislation is regulated in Act No 2 of 2012 concerning Land Acquisition for Development for Public Interest and Presidential Regulation Number 71 of 2012 in conjunction with Presidential Regulation Number 148 of 2015 concerning Implementation of Land Acquisition For Development For Public Interest. Based on the provisions of Article 47 Paragraph (1) of Presidential Regulation Number 148 of 2015, the Governor, with the authority he has, can organize land acquisition for the public interest, the establishment of a membership for land acquisition executors, the land acquisition implementation stage, an assessment of compensation, and deliberations on determining compensation. The obstacles faced in exercising local government authority in land acquisition for the public interest in Banyumas Regency are the amount of compensation proposed by the local government with land rights 
holders affected by land acquisition so that they are hampered in the process of implementing the provision of compensation, and solutions for This obstacle is the carrying out of public consultations and deliberations with people who do not agree on the amount of compensation so that consensus is reached.

\subsection{Suggestion}

Based on the research that has been described by the author in the previous chapter, several suggestions can be put forward which are expected to be used as input for policy makers related to land acquisition for the public interest of General Soedirman Underpass Development, Banyumas Regency, including:

1. Making implementation guidelines in the form of Regional Regulations, which detail the implementation of land acquisition in Banyumas Regency.

2. In land acquisition, the government as the policy maker should pay more attention to compensation. With this kind of pricing, the district government as the policy implementer will experience difficulties in land acquisition, especially since the land being sought is land that is easily accessible. The government should determine the price of land by looking at the NJOP, so that land prices will be adjusted to the location and condition of the land.

\section{References}

Journals:

[1] Kasenda, Dekie GG. 2015. Ganti Rugi Dalam Pengadaan Tanah Untuk Kepentingan Umum, dalam Jurnal Morality, Volume 2, Nomor 2

[2] Sembiring, Julius. Tanah Dalam Perspektif Filsafat Hukum, Jurnal Hukum.

[3] Berminas,Sonia Fabe. 2014.Proses Negoisasi Dalam PenetapanGanti Rugi

[4] Pengadaan Tanah Guna Kepentingan Umum, Journal of Politic and Government Studies, vol 3 No 3.

Books:

[1] Rajagukguk, Eman. (2012). Serba-Serbi Hukum Agraria: Tanah Untuk Kepentingan Umum, Larangan Alih Fungsi Tanah Pertanian, Landreform Tanah Pekarangan, Ed.1. Jakarta: Lembaga Studi Hukum dan Ekonomi Fakultas Hukum Universitas Indonesia.

[2] Salindheo, John. (1998). Masalah Tanah Dalam Pembangunan Ed.2. Jakarta: Sinar Grafika.

[3] Soimin, Soedharyo. (1993). Status Hak dan Pengadaan Tanah, Jakarta: Sinar Grafika. 
[4] Sutendi, Adrian. (2008). Implementasi Prinsip Kepentingan Umum Dalam Pengadaan Tanah Untuk Pembangunan. Jakarta: SinarGrafika.

Internet:

Pengadaan Tanah Untuk Kepentingan Umum, https://www.kompasiana.com/herybekasi/582e7e6623afbdbc048b4569/penga daan-tanah-untuk-kepentingan-umum, accessed on May 11, 2020, at 12:42. 